\title{
Energetics of Music and Performing Art as a Subject of Musicology
}

\author{
Aleksey A. Nikitin* \\ Khabarovsk State Institute of Culture \\ 112 Krasnorechenskaia Str., Khabarovsk, 680045, Russia
}

Received 23.03.2016, received in revised form 13.04.2016, accepted 27.05.2016

The article highlights the relevance of studying energetics in music, primarily, in musical performance that recreates a composer's work in live sound. The author offers his own definition of the concept of "musical energetics", gives a detailed description of this phenomenon; demonstrates perspectives of energetics research in musical art and art in general.

Keywords: energy, energetics, musical art, performance analysis, performance text.

DOI: 10.17516/1997-1370-2016-9-6-1419-1426.

Research area: art history.

This article is about what is absent in notes, but exists in sounding music, created by the composer, who puts vital force in its own creation that is preserved in it for centuries. This article is about the energy that permeated the contexture of sounding music, making the soul tremble, sensitively responding to its flows that master our whole existence.

This article is primarily generated by the surprise and desire to find an explanation of the historical phenomenon - the centuries-old not the vision of "elephant" in music art by musicology, its scrupulous study of minor items that do not affect the essence of music and are revealed in its energetics. The latter is visibly expressed in the work of the symphony orchestra conductor, who controls the energy flow that generates music: controls the degree of intensity and its distribution in different sound plans and dynamics of sound, builds a chain of climaxes, finishing by the general culmination where a powerful burst of energy and lessening of tension leading to the balance of power lines take place, and which confrontation creates the development of musical forms in time and space.

It should be admitted that on the intuitive and conscious levels musicology approached this topic several times, and finally has closely come to understanding of the necessity to study music energetics and even more - the energetics of art in general. More and more often the word "energetics" can be found in the everyday life of people of musical (and not only musical) art, there are calls to start its studies (M.A. Gotsdiner, A.A. Melik-Pashayev and N.I. Melnikova), articles and monographs on the energetics of art,

(C) Siberian Federal University. All rights reserved

* Corresponding author E-mail address: nikitinarts2011@yandex.ru 
in particular, such as the book by E.Y. Basin "Art and Energy" started appearing, which indicates of the fact that the "time has come" (Basin, 2010). And it has really come, as musicology, ignoring this topic obvious for performing musicians, especially jazz and rock musicians, ended in deadlock, without suggesting in the last thirty years any serious ideas, relevant to the compositional, performing and pedagogical practice.

In fact, for its centuries-long history, musicology, it would seem, has "discovered" everything, but it has also managed nearly take no notice of the essence of musical art, its live nature, expressed in energetics. Musicology gave preference to the speculative scheme, structure and form, confusing music with musical material - its "raw material" without being aware of the fact that music is not a material, specified by notes, but what is born directly in live sound and is the spiritual message reproduced by non-verbal means musical sounds, psychomotorics, emotions and vital power that has a diverse nature.

The experience of jazz and rock music listening and performance, as well as communication with the musicians of these styles, for whom energetics is a main channel to influence the audience and means of expression prevailing in their performing arsenal became an incentive for understanding the concept of "energetics of music" for the author of this article. Jazz broke stereotypes of classical music perception by playing with time and its unpredictability. "Deceiving" listeners' expectations, it keeps them on their toes, captivating them by emotionally and physically experienced rhythmic swing with multi-directed energies of rigid meter and rhythmic figures sliding over him with cascading syncopations, accents and off bit, everything what is called swing, without which, as you know, there is no jazz. The effect of rock music influence on the listeners mainly depends on the rock musicians' "drive" - the energy attack that casts a powerful audio stream on the audience.

A question, whether there is no energetics in academic music arose naturally. Whether an academic musician, at least intuitively, does not use the ups and downs of movement and sound, restraining and acceleration of the sound stream? Whether there is no difference in energy input (physical and spiritual) in waltz "La plus que lente" by Debussy and "Don Giovanni" by Liszt, "Melodies" by Tchaikovsky and the final of his violin concerto? These reflections and the analysis of the compositions of classical music and their performance convinced of the fact that in the music of other directions and other styles - folk, spiritual and classical, there is also energetics, but in a different qualitative expression.

The appearance of this article is generated not only by surprise and the above mentioned reflections, but also deep dissatisfaction with the relationships of music theory and practice, the weak demand for the first in the latter, especially in performance and pedagogics. In the composers' works today, a lot of composers without deep theoretical knowledge manage to compose their "opuses" with the help of computer and synthesizer from the standard cubes-models of musical "Lego".

This dissatisfaction was expressed at the beginning of the last century by E. Kurth, who initiated the study of the nature of musical energetics: "The establishment of a close connection of theoretical studies with stylistic and psychological preconditions can seem unusual and even unattainable. It is possible to explain this doubt by the fact that the usual concepts of music theory, especially distributed in a distorted way in the process of teaching in general can no longer be connected with big art. Low level of education, blunt dogmatic scholarly approach and routine, unseen in other territories a long time ago led to the fact that the real talents rebel against 


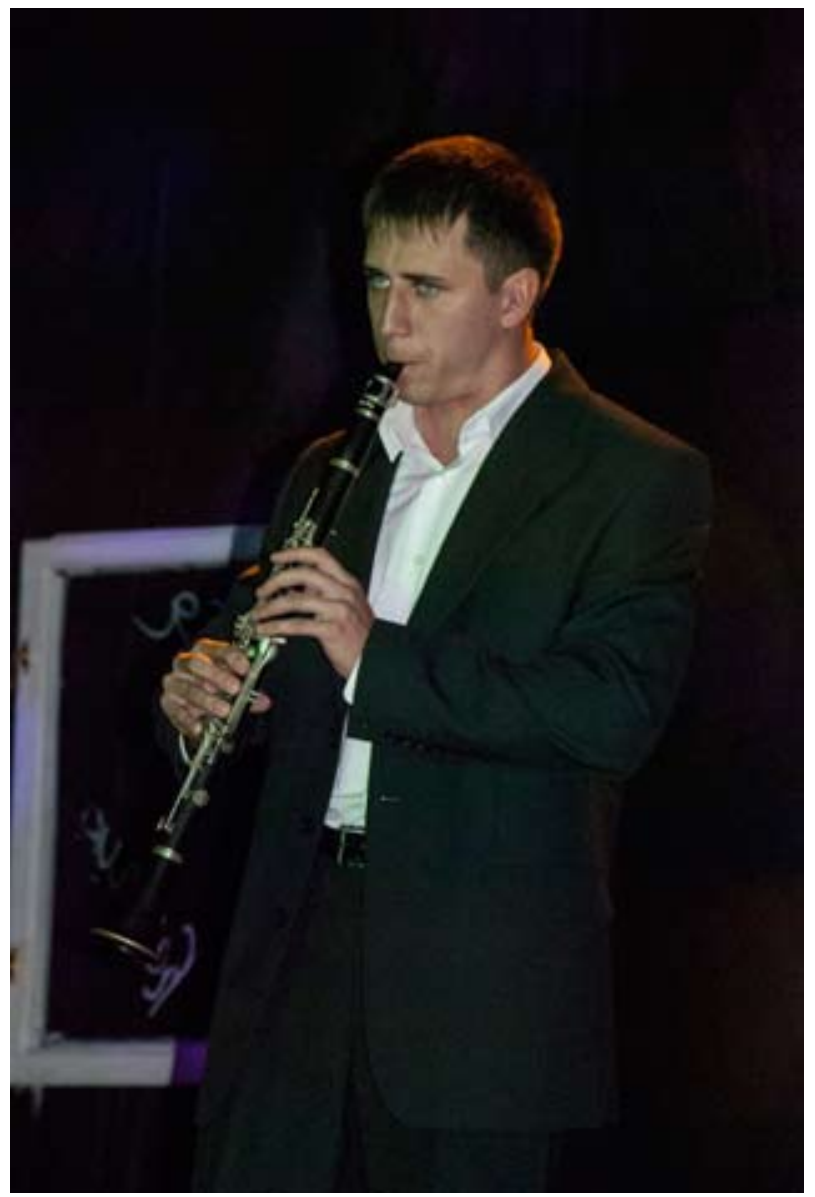

combination of such theory with practice and live creativity. On the other hand, a tragicomic culmination of the prevailing misconceptions lies in the fact that musicology of our time has come to considering theory as an auxiliary technological subject, which, if not completely superseded by it from the sphere of science, then, at least, is put into the infamous corner. In fact, theory is the true essence of musicology, its most lively part and the foundation that is not only closely related to the art, but becomes its direct reflection in all its manifestations"(Kurth, 1975: 11-12). And further: "The study of transformation of specific intensity processes in consonance is a fundamental task of the whole music theory. Only in this way it is possible to awaken the feeling of live creative forces in theoretical observation, to get into their spirit and merge with them, reconstructing a long time ago broken connection between theory and art. For those, who will be able to comprehend this inner life formation of harmony, music will turn from the symphony of sounds into the symphony of energy flows that manifest themselves in a wide stream of sound development" (Kurt, 1975: 16). The ideas expressed by the eminent Swiss musician and theorist of music 90 years ago are particularly relevant today.

This dissatisfaction is also generated by the lack of serious theoretical basis for a musical composition performance analysis in clear and precise terms. Available analytical instrumentarium is based on theoretical analysis of musical composition in the universal form, not operating such concepts as "text" in the hermeneutic and linguistic sense and "performance text" that is born in the process of 
making performance interpretation. Traditional theoretical analysis does not penetrate into the substantial deep layer of music, disjointing its body, but without affecting its spirit - the primary force, which gives life to music, as A.F. Losev eloquently said at his time: "Of course, it is possible to "analyze" a musical composition, decomposing it to the "components", finding different kinds of "symmetry" in it, etc. But, as well as parts of a living organism are not parts of a living organism, as in reality they are separated from it and do not live the same life with it, and parts of a musical composition are only parts when the general image of the composition, not consisting of any parts and, nevertheless, giving them real life and living in them, is taken into account" (Losev, 1990: 230-231).

It is high time for musicology to move from studying dead schemes to the study of live musical materials, which is reborn each time thanks to the energy of a performing musician's efforts of will. And here again we would like to recollect E. Kurth, claiming that in theory the study of phenomenon should begin with the basic live process, from the moment of the internal efforts breakout and their formation in sounds. Otherwise, moving in a circle, it can be out of music and get lost in the red tape and schematism.

Music is art connected with the organization of sound fabric in time; sound flow that requires energy, which nourishes it. This movement is a sequence of efforts and letting out of energy. "Pure musical existence is all permeated with endless energies and strengths, it is something constantly swelling and trembling, live and nervous. Every moment in musical composition is permeated with countless strengths; it is a kind of a center and focus of vital currents of the whole organism. The whole musical composition is a living system of indivisible energies interpenetrating each other; they are a real unity of intersecting reasons that are simultaneously the action of these reasons as well", stated the great Russian thinker A.F. Losev (Losev, 1990: 240).

Music is also space and time art that needs a specific physical space requiring the appropriate energy for its coverage and content, which might be concentrated in a particular sound plan of musical texture. Actually, sound as an elementary particle of music is a flow of energy, an electromagnetic wave of a certain length and amplitude that causes air vibration, and impact on us by the vibration. We are referring to the physical parameters of the energy enclosed in music - the power (volume) of sound, intensity, extensity, duration, nature, form of energy and oscillation of frequency (hertz). But the energy of music is not only physical energy. Its structure also includes psychic (emotional energy) and spiritual energy, i.e. the energy of a musical composition's author and its performer. The fate of a musical composition, to a large extent, is dependent on the latter, on the performer's life, spiritual and creative energy, since a composition is eventually what a performer makes of it.

An outstanding Swiss musicologist Ernst Kurth, whose teachings on this phenomenon was enthusiastically adopted by B.V. Asafiev, was a pioneer in the study of music energetics. Great contribution to the study of music energetics was made by a Russian scholar and encyclopedist A.L. Chizhevsky, in aesthetics by A.F. Losev, in psychology by C.G. Jung, in performing arts by K.S. Stanislavsky, in cinema by S.M. Eisenstein and in visual arts by R. Arnheim and V. Kandinsky.

What is music energetics? For the majority of professional musicians and music lovers energetics is reflected in the performing musician's temperament, his/her ability to captivate, the ability to "sweep" the listener and the viewer, to make a strong emotional impact on them. Quite often we are faced with a primitive and even false understanding of energetics, when blunt 
anguish, aggressiveness, hysteria, the vocalist or instrumentalist's turning him/herself inside out and singing or playing on the verge of a nervous breakdown are considered as its signs.

Energetics is often confused with dynamics in the narrow sense of the concept, when it is understood as sound volume, the number of decibels let on the listener, which is especially characteristic of hard and punk rock. But the concept of "dynamics" and "energetics" are not identical, although they are interrelated. Dynamics, first of all, is a physical category, one of the parameters of musical fabric, and energetics is a spiritual category associated with the power of a musician's spiritual expression.

Energetics of musical and performing arts is intensiveness, extensiveness and duration of the spiritual light of the musician personality. This is possession of different types and forms of musical energy, its flows contained in the sound fabric of a musical composition and energy distribution in time and space in different sound plans; it is the ability to compress and stretch the time and the sound fabric and saturate it with electric discharges of emotions.

Musical energetics possession is the ability to manage power lines and their directions, creating either tense or uncharged energy field; it is possession of types and forms of energy in a particular cultural context; it is the ability to build a chain of energy waves, leading to a climax and then to strain reduction, to the balance of powers, causing catharsis.

Energetics of musical composition can also be characterized as a sequence of energy "tide rises" and "low tides", ups and downs. The power of this energy is of a huge range - from easy gliding on the surface of the sound wave ("energy surfing") up to a powerful rise or explosion. Energetics of musical performance has many types and forms and uses different strategies depending on the purpose of the performing musician (persuade, captivate, entertain, fascinate, suppress, crush, inspire, delight, etc.). Possessing music energetics is, in fact, possession of space and time - a musical chronotope. Taking possession of music energetics is a peak of performance skills.

Music energetics is not recorded in musical notation. The musician has to find it him/herself, to decrypt, to comprehend and to understand its variability depending on mood, weather, audience, acoustics of the hall and other factors. In fact, the ability to build up the energetic component of a musical composition is its interpretation that creates performing text, which can not be created once and "for ages", but every time will represent a new version of the game with time and space, line, mass, colors, sound plans and, of course, with the listener. Energetics is a configuration of power lines, overlapping, intertwining or co-existing in combination in the sound fabric of a musical composition. This configuration is created by various forms of musical energy, corresponding to the cosmic energy, according A. Chizhevsky: the energy of explosion, light, flow, wave and field.

The energy of explosion may have different power and scale - from lightning flashes and emotional outbursts to a cosmic explosion (A. Scriabin "Preliminary Steps"). The energy of explosion is not subjected to any form, but it generates a form of energy, which appears after the explosion. The explosion becomes a source of energy of the arising musical form, determines its structure and dynamics.

Light energy also has a huge range of gradation, from the soft light of twilight, the first signs of dawn to the glaring light. This may be the triumph of light, like in "The Poem of Fire" or in "Prometheus" by Scriabin; the light from the fire that changes form, giving a bizarre symphony of flecks (De Falla's "Ritual Fire Dance"); it can be the light of a distant star twinkling in the sky, the cold light of fireflies, the fantastic light of "friar's 
lantern" or the sinister "St. Elmo's fire" terrifying the seafarers.

The energy of flow appears in music in a variety of forms - from the streaming flow of light to rapid spontaneous, sweeping away everything in its path. The nature and the material shell of this flow may vary: light transparent and playfully ironic ("Perpetual Motion" by Weber and Paganini), enthusiastic and jubilant (S. Rachmaninov, romance "Spring Waters", the final of piano concerto №2) or aggressively attacking (the final of Sonata no 7 by S. Prokofiev).

Wave energy in music is represented more fully and abundantly as the most common form of energy in it - from "light ripples" to the devastating tsunami. It can be the energy of a natural disaster, recreated in music; a cascade of waves, simulating an event, its procedurality, such as a historical event (Prokofiev, music from the film "Alexander Nevsky" - "The Battle on the Ice"); it might be the "waves" of lyrical experiences of the hero of a musical composition, his various emotional states.

Field energy is a form of energy rarely found in music, evidence as if of the absence of energy, but it has a great strength of influence, especially in comparison with other forms of energy as their alternatives. This form of energy, with its apparent uniformity, has a lot of modalities. It can be concentrated and contemplative (C. Debussy, Prelude "Footsteps in the Snow"), dead and lifeless, filled with a barely perceptible vibration of vital forces (M. Mussorgsky, "Pictures at an Exhibition" - "With the Dead in a Dead Language"), it can be religious and humble, detached and full of divine grace (F. Liszt "Dante Sonata" the second theme), etc. In music, we often meet the combination of different forms of energy in one composition. For example: Polonaise No. 1 by Chopin $\mathrm{C}$ sharp minor, F. Chopin, Fantaisie in F Minor, R. Schumann Fantasy in C Major, F. Liszt "Mephisto Waltz", Sonata in B Minor, etc.
We know a lot about the imaginative side of music, its intonational nature, style, form and content, but it all either does not have a direct relationship to the live music, or is exposed metaphorically, vaguely, from the scientific point of view, and relies more on the implicit knowledge and intuition. Outlook from the perspective of art energetics allows us to give an explicit explanation to a lot of musical phenomena and processes, build a convincing logic of a musical composition and the musical meaning deployment, to justify its dramatic composition, the driving forces of the form as a process and to identify the author's style, specific features of his personality and thinking. Energetics encourages the performing musician to organize space and time, mass and speed with almost mathematical precision, to build the strategy of the energetic "attack" on the listener, to calculate the flow of emotions, the game of plan and "actors". Instead of "sighs", more or less precise associations and comparisons, the performer gets wonderful instrumentarium for comprehending the author's text and embodiment of the musical image. Energetics of musical performance is a new trend in musicology, which will soon be transformed into a scientific discipline "Energetics of Musical Art"; this is a new world, opening to the artistic consciousness, comprehending the mysterious and inexhaustible nature of music.

Relevance of the study of musical and performing arts energetics is determined by a lot of factors, among which the most obvious will be identified:

1. The procedural understanding of musical form, coming from B. Asafyev and his fundamental work "Musical Form as a Process", created under the influence of energetic conception of music by E. Kurth that is described in the works of the Swiss theorist "Romantic Harmony and its Crisis," "Linear Counterpoint" and "Tonpsychologie". Reflection of this concept 
today is manifested in the emphasizing the intonational nature of musical creativity.

2. Finding a huge "white spot" in musicology, artistic performance and music pedagogy connected with the study and comprehension of the musical art energetics that is not limited by actualization of intonation in composing and performing art. Intonation, so respected by musicologists, is only the external expression of deep vital forces, similar to waves on the sea surface. But the waves are not all the sea! This is just its surface, "light ripples", but his true nature and the power are in the mysterious and incomprehensible depths - the receptacle of the powerful and inexhaustible energy. Here it is possible to draw a parallel with the theatre art where K.S. Stanislavsky saw the second inner energetic plan. Relying on self-observation, he came to conclusion that in addition to "visible" by sense organs means of information transmission and exposure through the "external communication" there is a special kind of energy, which moves inside man, comes from man and is directed at the subject. Stanislavsky saw the advantage of "internal" communication in a fact that it is a "thin", "powerful" and "profound" tool to transfer the invisible, undescriptible spiritual essence of the composition. Internal communication reminds Stanislavsky of undercurrent, which constantly moves under the words in silence and forms an invisible connection between the actors, thereby forming the "internal link". The director considered "invisible" communication the most scenic one in the transmission of the human spirit life, the one that cannot be conveyed by a word or a gesture.

Intonation theories that became fundamental in Russian musicology will have to give "the palm of victory" to energetics that asserts its primacy in the essential expression of music.

3. The acquisition by performing practice and pedagogy with the help of music and the performing arts energetics of a strong theoretical framework that allows to explain the nature of music, its live fabric, becoming in time and space musical form in clear terms and concepts.

4. The vision of immense prospects for musicology's inclusion into music energetics unexplored galaxy, where music is presented in its original form, where the new worlds are opened up, which research will take at least a century from the energetics of a single tone, melody and harmony, texture and musical form to energetic "portraits" of composer and performing schools, music flows, styles and trends. The creation of a new science of music is apparent - the energetics of musical arts and even the energetics of art in general that were initiated by S. Eisenstein, K.S. Stanislavsky, R. Arnheim and V. Kandinsky in the first half of the last century.

Energetics of musical art as an object of scientific consideration can be manifested in the following types of music activities:

- in a creative productive act - in the process of composing a piece of music or improvisation;

- in performing arts;

- in the perception of music;

- in music pedagogy;

- in musical criticism.

The author believes that the most important task of musicology of the $21^{\text {st }}$ century is study of the huge energetic potential of musical art aimed at more effective impact on people's souls, their spiritual and physical transformation; creation of a modern analytical and performing instrumentarium for the comprehension and transmission of value-semantic, as well as ideological and comprehensive essence of music; creation of performing text as close as possible to the composer's intention.

At the center of scientific research of energetics there should be meaningful and conceptual aspect of music, which consideration 
is not possible without the pedagogical aspects of music energetics, that should be studied not only by aspiring musicians but by the professional performing musician as well, as music energetics possession has a lower limit, but does not have the upper one.

\section{References}

Basin, E. Ya. [2010]. Iskusstvo i energiia: Psihologo-esteticheskii aspect [Art and Energy: Philosophic and Aesthetic Aspect]. M, 256.

Kurth, E. [1975]. Romanticheskaia garmoniia i ee krizis v "Tristane" Vagnera [Romantic Harmony and Its Crisis in "Tristan” by Wagner]. M, Muzyka, 551.

Losev, A.F. [1990]. Muzyka kak predmet logiki. Iz rannikh proizvedenii [Music as the Subject of Logic. From Early Works]. M, Pravda, 410.

\section{Энергетика музыкально-исполнительского искусства как предмет музыкознания}

\section{А.А. Никитин}

Хабаровский государственный институт культуры Россия, 680045, Хабаровск, ул. Краснореченская, 112

В статье подчеркивается актуальность исследования энергетики в музыке, прежде всего в музыкальном исполнительстве, воссоздающем в живом звучании произведение композитора. Автор статьи предлагает собственную дефиницию понятию «музыкальная энергетика», дает этому феномену развернутую характеристику; показывает перспективы исследования энергетики в музыкальном искусстве и искусстве вообще.

Ключевые слова: энергия, энергетика, музыкальное искусство, исполнительский анализ, исполнительский текст.

Научная специальность: 17.00.00-искусствоведение. 